Canadian University Music Review

Revue de musique des universités canadiennes

\title{
Introduction to Man and Music/Music and Society Series
}

Paul F. Rice

Numéro 15, 1995

URI : https://id.erudit.org/iderudit/1014399ar

DOI : https://doi.org/10.7202/1014399ar

Aller au sommaire du numéro

Éditeur(s)

Canadian University Music Society / Société de musique des universités

canadiennes

ISSN

0710-0353 (imprimé)

2291-2436 (numérique)

Découvrir la revue

\section{Citer ce document}

Rice, P. F. (1995). Introduction to Man and Music/Music and Society Series. Canadian University Music Review / Revue de musique des universités

canadiennes, (15), 158-159. https://doi.org/10.7202/1014399ar

All Rights Reserved (C Canadian University Music Society / Société de musique des universités canadiennes, 1995
Ce document est protégé par la loi sur le droit d'auteur. L’utilisation des services d'Érudit (y compris la reproduction) est assujettie à sa politique d'utilisation que vous pouvez consulter en ligne.

https://apropos.erudit.org/fr/usagers/politique-dutilisation/ 


\section{REVIEW/COMPTES RENDUS}

\section{Introduction to Man and Music/Music and Society Series}

We begin a series of reviews devoted to the volumes of the Man and Music/ Music and Society series under the general editorship of Stanley Sadie and distributed in North America by Prentice-Hall Incorporated. The stated goal of the eight volumes of this chronological series is to examine the Western European music tradition within a broad context of extra-musical considerations. The books are not intended to constitute a traditional, comprehensive history of music; indeed, the reader looking for such information will likely be disappointed. Instead, the "intention is to view musical history ... as a series of responses to social, economic and political circumstances and to religious and intellectual stimuli." Given this premise of viewing music as resulting from specific external forces, the various authors have been charged with the responsibility of going beyond the recitation of mere factual details to explaining why musical events unfolded in a particular way.

Each volume consists of essays by different authors under the direction of a volume editor. Each volume begins with an introductory essay of a more general nature written by the volume editor. This is followed by essays which, in most cases, focus upon the musical events of a specific city, region or country. The emphasis is upon the Western European musical tradition; however, the centres of musical activity discussed also include areas outside that geographical context where significant influence of this tradition has been experienced. Such an approach cannot hope to result in a comprehensive view of the history of music. In place of that goal is the "hope, however, that a new kind of picture of musical history may begin to emerge from these volumes, and that this picture may be more accessible to the general reader."

Some explanation may be necessary for the use of two different series titles. The books were intended to supplement television programmes called "Man and Music", made by Granada TV in the United Kingdom in the mid-1980s. The books were "informed by the same general approach, though of course for a rather different audience." 3 Two volumes in the series had already been published under the same general title, Man and Music, when the North American distributor requested an alternate title to avoid any possible discrimi-

1 Stanley Sadie, Preface to each volume of the series.

2 Sadie, Preface.

3 Stanley Sadie, private correspondence, 17 October 1994. 
natory connotations. Thereafter, the series title of Music and Society was adopted for North American distribution, while the original series title has been retained in Europe. Thus, the change of the general title does not represent any change in approach in the series; all eight of the volume editors worked from the same set of governing principles.

Paul F. Rice

James McKinnon, ed. Antiquity and the Middle Ages: From Ancient Greece to the 15th Century. Music and Society. Englewood Cliffs: New Jersey, 1990. x, 337 pp. ISBN 0-13-036153-4 (hardcover), ISBN 0-13-036161-5 (paperback).

1. James McKinnon: "Early Western Civilisation"; 2. Andrew Barker: "Public Music as 'Fine Art' in Archaic Greece"; 3. James McKinnon: "Christian Antiquity"; 4. James McKinnon: "The Emergence of Gregorian Chant in the Carolingian Era"; 5. David Hiley: "Plainchant Transfigured: Innovation and Reformation throught the Ages"; 6. Marion S. Gushee: "The Polyphonic Music of the Medieval Monastery, Cathedral and University"; 7. Peter M. Lefferts: "Medieval England, 950-1450"; 8. Christopher Page: "Court and City in France, 1100-1300"; 9. Daniel Leech-Wilkinson: "Ars Antiqua - Ars Nova - Ars Subtilior"; 10. Michael Long: "Trecento Italy"; 11. Reinhard Strohm: "The Close of the Middle Ages".

Few would question the need for a book designed to illuminate the relationship between music and society before the Renaissance. Of all music's stylistic periods, the Middle Ages is arguably the one for which this relationship remains most dimly perceptible. Medieval studies in music have been preoccupied with sources and texts (both musical and theoretical) because there were so many to be worked through, and because there are so few which easily furnish much information about the societies from which they emerged. Unfortunately, it must be questioned whether this volume really represents much of an advance. It succeeds in so far as revealing how much remains to be learned, or at least, hypothesized, and in highlighting many of the questions which scholarship has neglected or failed to explore. In fairness, it must be pointed out that it is much easier to identify such questions than to find answers, or even to know where to look.

Contrary to what the series' Preface and dust-jacket material promise, a good deal of the volume consists of historical survey - "what happened" - ignoring the promises about the "why it happened" (ix). David Hiley's chapter on medieval plainsong creates a long series of frustrations, describing or mention- 